\title{
The Past in the Present: Historical and Rhetorical Lineages in China's Relations with Africa*
}

\author{
Julia C. Strauss
}

\begin{abstract}
China's official rhetoric on its relations with Africa is important; it frames, legitimates and renders comprehensible its foreign policy in this ever-important area of the world. This article explores the following puzzle: why China's rhetoric on its involvement with Africa has retained substantial continuities with the Maoist past, when virtually every other aspect of Maoism has been officially repudiated. Despite the burgeoning layers of complexity in China's increasing involvement in Africa, a set of surprisingly long-lived principles of non-interference, mutuality, friendship, non-conditional aid and analogous suffering at the hands of imperialism from the early 1960s to the present continue to be propagated. Newer notions of complementarity and international division of labour are beginning to come in, but the older rhetoric still dominates official discourse, at least in part because it continues to appeal to domestic Chinese audiences.
\end{abstract}

Official rhetoric (seeking to persuade), historical narrative (the supporting stories about what has happened), the presumptive audience(s) the rhetoric seeks to persuade, and the politics and concerns of the time in which the rhetoric is propagated are deeply entwined; as audiences, topical concerns and political leaders themselves change, so too should the rhetoric and the narrative. This article explores the following puzzle. Why in China is there at present still such a relative uniformity of discourse on Africa, when the actual conditions of China's relations with Africa are so multifaceted and varied, and why is this discourse so eager to claim itself part of an unbroken lineage back to the revolutionary 1960s, 1970s and even earlier, when virtually every other facet of the Mao revolutionary years has come under intense criticism? I suggest that these rhetorical continuities are neither implicit nor accidental. On the contrary, China's current official and semi-official statements and representations of China-Africa relations self consciously and deliberately situate current Africa policies and initiatives in

\footnotetext{
* Special thanks are due to Dan Large, Jamie Monson and R. Bin Wong for their careful readings of earlier versions of this paper.
} 
a distinguished lineage of principled relations, even when the actual links are at best tenuous and the substantive content radically transformed. Thus the People's Republic of China (PRC) continues to trumpet its past 50-odd years of involvement in Africa as positive, progressive and grounded in the eternal and principled truths of non-interference, mutual benefit, unconditionality, and special friendship and understanding towards Africa.

Not surprisingly, this discourse skates over some of the realities in which China has been rather less happily involved. These include supporting weak regimes and/or receiving leaders on the eve of their overthrow (Nkrumah in 1966); flagrantly (and covertly) arming and aiding presumptively revolutionary rebellions (Rhodesia/ Zimbabwe, South-West Africa/Namibia, Guinea/Cape Verde, Cameroon, Congo, Algeria at different points from the early 1960s to the late 1970s) while publicly preaching non-interference and mutual benefit; engaging in grubby competition with the Soviet Union (notably Angola and Mozambique in the 1970s); and continuing to be entangled with regimes whose human rights records have come under widespread criticism (particularly Sudan and Zimbabwe) in the present. ${ }^{1}$

The purpose of this article is not to detail the ways in which practice diverges from rhetoric. Post-Westphalian states all exhibit significant gaps between what they say and what they do. I take it as a given that whatever the principles articulated through foreign policy rhetoric, real life actions will often differ from those principles, and will probably be interpreted by others outside the generation of the rhetoric with some degree of scepticism. China can certainly be criticized on these grounds, but in a decade in which the United States government has trumpeted its military involvement in Iraq in terms of democracy and the desires of the Iraqi people, it is obvious that China is hardly unique in this respect. Rather, the article aims to take seriously China's grounding and framing rhetoric of its policies towards and actions in Africa. In so doing, it charts how China's official and semi-official discourse on Africa reveals at least as much about elite policy-making hopes, aspirations and sense of place in the world as it does about China's burgeoning and multi-layered actual involvement in the increasingly complex and varied realities of Africa. In this respect this article makes no claims as to the ways in which the rhetoric and aspirations will practically translate into policy; indeed one of the main points is that the framing rhetoric on China-Africa is so deeply rooted that it has shown a remarkable ability to encompass wildly different initiatives and policy outcomes over what is, by the standards of virtually all foreign policy making, an unusually long time. Nor has the rhetoric remained completely unchanged. Large chunks have been unceremoniously dropped to suit other changes in policy: for example, there was a great deal of official reporting on China's aid for movements of national liberation in the 1960s and 1970s which has since quietly lapsed. Nevertheless what

1 See Philip Snow, The Star Raft: China's Encounter with Africa (London: Weidenfelt and Nicolson, 1988), particularly p. 78, map 3, "Chinese support for African insurrections since 1949," and pp. 121-34. 
has been retained is telling, and a significant core of rhetorical framing positions about China's intentions and activities in Africa from the early 1960s is still very much present today.

This study suggests that rhetoric is not merely "empty words" to discount before peering into the somehow "harder" reality of China's intentions and actions. In China as elsewhere, official and semi-official rhetoric provides the framework within which policy and initiatives are developed, explained and legitimated both domestically and internationally. Rhetoric is part of a complex of critical appeals between the state and significant audiences it wishes to attract, persuade, mobilize or consolidate support within. In China as elsewhere, reality in policy implementation often departs from stated ideals, but the grounding rhetoric continues to matter to a range of different audiences, both domestic and international. Official rhetoric is also significant as the framing within which policy is articulated. Hence it includes "givens" that Chinese policy makers and elites do not need to question, offers a shorthand for the limited knowledge about Africa the Chinese population at large encounters, and sets forth a set of legitimating claims about China's intentions towards international actors, particularly in Africa itself.

In order to chart this discourse, this article concentrates on four particular bursts of China's official and semi-official coverage of China-Africa affairs, most of which have occurred around the time of important official visits and/or exceptionally high-profile international conferences. The four are, first, Zhou Enlai's great Africa tours of 1963-65; second, reporting on the TAZARA railway construction from 1967 to 1976 and the way in which the project is currently represented in China; third, Jiang Zemin's African tour of May 1996; and finally, official speeches given at the first, second and third Forum on China-Africa Co-operation (FOCAC) meetings in 2000, 2003 and 2006 in Beijing and Addis Ababa that are currently available on the FOCAC website.

Despite the reality of significant change within the broad realm of ChinaAfrica relations - both within the Mao revolutionary years in the 1960s and 1970s and between then and the more recent trends since the mid-1990s - there has been surprisingly little alteration of the fundamental framing categories propagated by China's official and semi-official discourse. Although significant chunks of the old rhetoric that supported movements of national liberation have been dropped and what remains struggles to contain a new set of complex realities that threaten to burst beyond what it can accommodate, very little that is new has been added. Even as it begins to show signs of fissure, China's discourse on Africa continues to propagate a vision of China as a uniquely moral international actor. This might well jar with external sensibilities when attention is turned to China's public support for highly repressive regimes (Sudan and Zimbabwe are the cases that spring immediately to mind). But within China, long-standing notions of its own exceptional morality draw on a deeper and indeed consistent set of logical supporting ideas.

First is that China is untainted by a history of colonization in Africa, in at least implicit comparison to the West. Second is the perception that China is uniquely 
suited to assist Africa from a position of analogous but separate history of anti-colonial struggle, underdevelopment and representing "old splendid civilizations." Third are the repeated initiatives to assist Africa in a spirit of co-equal friendship that emphasizes China's own developmental experience, leading to eventual African self-reliance rather than perpetual superior-inferior tutelage and dependency. Fourth is China's absolute insistence on the principle of strict non-interference in domestic affairs while upholding norms of state sovereignty. Linked with this is a reiteration of China's superior moral constancy as an "allweather friend," implicitly unlike the West, which constantly changes its colours and demands on Africa in terms of accountability, transparency, structural adjustment and so on. Finally, all of the above are reinforced by the sheer repetition of particular historical episodes that supports these points.

All these factors in turn undergird a developmental model for Africa that is at least implicitly deemed both separate from and better than what the West (or in its time, the Soviet Union) has had to offer. For decades, China has claimed to be a poor and developing country, and its presumptive developmental successes, both in the revolutionary Mao years and in the present, illustrate a range of possible ways forward for Africa. Having suffered an analogous history of underdevelopment and colonialism, China positions itself as uniquely situated to help Africa on the basis of mutual benefit, non-conditionality and demonstration by example. Taken in aggregate this is a heady and convincing package, one that resonates with much older Chinese notions of statecraft as didactic morality and softens contemporary anxieties about place in the world, thus allowing China to claim to be both old and new, separate and better, national and international. In short, key elements of the rhetoric continue to be very attractive to a range of audiences within China itself, particularly against a backdrop of increasingly voiced nationalism from below.

Unlike the changeable West, which promotes a range of different rhetorics to justify radical changes in policy direction roughly every decade, the consistency of China's rhetoric on Africa makes it possible for it to make a credible claim to be Africa's "all-weather friend" and appeal broadly to African elites. In a range of different circumstances in different times, various groups in Africa have also found parts of this rhetoric attractive enough to engage in flirtation, engagement and outright adoption, but the degree to which this has held is the subject of another article. For China, what stands out is how consistent the dissemination of this discourse has been over the last half-century; flexible enough to continue to frame changing content and even accommodate quite radical changes in policy direction, even as it now sits increasingly uncomfortably with a new, rapidly escalating set of interactions with Africa that logically threaten to bring down the rhetoric altogether.

\section{Zhou Enlai's First African Tour of 1963-64: the Cold War Context of the First Charm Offensive}

Virtually all the contemporary official and semi-official discourse on China's involvement with Africa stresses history, and in so doing, selectively highlights 
particular events. Typically, the PRC's claims are justified by what slim evidence there is for indirect contact between China and Africa from late antiquity onwards. Most of the official discourse is launched with an abbreviated historical review, and nearly all of these make much of the Zheng $\mathrm{He}$ 郑和 seafaring voyages to East Africa in the 15th century. Accounts of the Zheng He voyages invariably distinguish the mutual curiosity, trade and impermanence of the Chinese voyagers who left Africa after a brief period, and European colonizers who arrived shortly afterwards and remained as colonial dominators. ${ }^{2}$ The PRC also interprets its own history of involvement in Africa, and contemporary official chronologies and historical reviews of China-Africa relations stress the early links between the young PRC and "Africa" (or, at least, a solid subset of important countries in Africa). These links are condensed into a grand teleological march of the consolidation of international respectability and wider formal recognition of the PRC, notably in the establishment of formal bilateral diplomatic relations, and Africa's subsequent collective support for China in joining the United Nations. Thus Egypt takes pride of place as the first African country to establish diplomatic relations with China (1956); by the early 1960s, over ten African countries had done so, and by the end of the 1970s, 44 of the 50 independent African countries had officially recognized the PRC. ${ }^{3}$ The revolutionary years, which involved (among other things) Zhou Enlai's famous tours to Africa in the early 1960s and China's later sponsorship of the TAZARA railway (constructed between 1969 and 1976) are also represented as important base components of this official lineage.

Since Zhou Enlai's big tours to African countries in 1963-65 were so fundamental to this grounding legacy, as well as being such highly public events at the time, they are worth discussing at some length. Between December 1963 and February 1964, Zhou visited ten African countries north of the equator. Of these, four were Maghrebi (The United Arab Republic, Algeria, Morocco, Tunisia), two were West African (Ghana, Guinea), two were East African (Ethiopia and Somalia), and two straddled the borders between north and south (Mali, Sudan). In June 1965, Zhou made a significant trip to Tanzania. During these visits, Zhou engaged in the highly effective public diplomacy that was to establish exactly the kind of image of China that continues to be resonate so strongly in the discourse on Africa in China today: the essential morality of

2 One contemporary written example of this is Tian Peiliang, "China and Africa in the new period," at http://hollerafrica.com.showArticlee.php?catId=1\&artId=37, accessed 3 June 2008. Tian is the director of the Department of Asian, African and Latin American Affairs at the Chinese People's Institute of Foreign Affairs. An arguably more influential source is CCTV, which has produced a series of documentaries on China and Africa entitled China-Africa: Sharing A Common Fate, of which one instalment is "Africa-China trade: a history" and another is "China's investment in Africa." Both are currently available on YouTube. See also Snow, The Star Raft, pp. 1-36. Zhou Enlai's address to a mass rally in Mogadishu in 1964 also grounded the contacts between the Somali and Chinese people in the Zheng He visits. "Premier Chou En-lai: revolutionary prospects in Africa excellent!" text reproduced in Peking Review, No. 7, 14 February 1964.

3 "A chronology of China-Africa relations - Beijing review," http://bjreview.com/backgrounder/txt/ 2006-12/10/content_50421.htm, accessed 17 June 2008. 
China's action in Africa, a clear delineation of China from the West in its dealings with Africa, absolute respect for state sovereignty, a friendliness grounded in notions of equality rather than superiority, support for anti-colonial struggles, no-strings developmental assistance, and notions of supporting self reliance.

"Africa policy" and the discourse on China-Africa did not emerge full blown at the time of Zhou's first Africa tour. By 1963, the revolutionary PRC had established relations with Egypt, projected much of its own recent struggle with imperialism with sympathetic rhetoric in support of various anti-colonial struggles, particularly in Algeria, and managed to establish formal relations with a handful of relatively sympathetic countries. As early as 1961, the Institute of Asian-African Studies was established under the joint sponsorship of the Central Party External Ministry and the Chinese Academy of Social Sciences, after Mao admitted in April of that year that "knowledge on Africa was lacking"4; this is all the more notable because 1961 was the nadir of the "three bad years" of famine in the aftermath of the Great Leap Forward, and was otherwise a time of ongoing leftism and severe bureaucratic retrenchment.

In the context of 1963-64, however, the first of Zhou's Africa tours signalled a return to the relative moderation, flexibility and civility of the mid-1950s after the domestic and international radicalization of the late 1950s with the Great Leap Forward, the Taiwan Straits crisis, and a series of Sino-India border incidents culminating in the border war of 1962. Ironically, the Five Principles of Peaceful Co-existence so often reiterated over the course of the past 50 years were worked out with India in 1954 in order to avoid exactly the kind of tensions and border incidents that erupted a few years later. As early as 1955, the PRC positioned itself as part of the non-aligned developing world at the first Asian-African conference at Bandung, at which it was a signatory to the unanimously agreed "Bandung Principles" which became the foundation for later gatherings of the non-aligned movement. As the Five Principles of Peaceful Co-existence and the Bandung Principles have since been reiterated to the point of fetishism and have provided the bedrock of most official statements on China-Africa since Zhou's first Africa tour, it is useful to take a look at the context of their original articulation.

The Five Principles were propagated against a background of deepening Cold War, unresolved tensions between unclear borders and the status of Tibet between India and China, and a period of relative mildness in China's domestic and foreign policy in the immediate aftermath of the Korean War. They were agreed between India and China in 1953-54 to ease strains between two of the more important land powers in Asia, and as such were geared to a strictly post-Westphalian set of notions. The Five Principles were: reiterating the sanctity of territorial integrity and state sovereignty, mutual non-aggression, mutual noninterference in internal affairs, equality and mutual benefit, and peaceful co-existence. 
A year later the Bandung Principles, which formed the core ideals of the nonaligned movement in the early 1960s, reiterated all the above in slightly different language, and added even higher-minded principles of human rights, the equality of all races and states, respect for states defending themselves in conformity with the charter of the United Nations, and abstention from joining collective defence to serve the interests of big powers. They also included abstention from exerting pressure on other countries, settlement of disputes by peaceful means, promotion of mutual interests and co-operation, and respect for justice and international obligations. Perhaps predictably, the actual implementation of the Bandung Principles was extremely uneven, and subsequent efforts to expand the nonaligned movement in the early 1960s fell apart under a combination of stresses from the Sino-Soviet split and the inability of many developing countries to keep to their principles of non-interference and peaceful resolution of disputes; indeed, the Five Principles of Co-existence and the Bandung line so trumpeted at the time of Zhou Enlai's first tour to Africa in 1963-64 and reiterated ever since were honoured more in the breach, not least by China itself.

Zhou's first major tour to Africa involved public statements to a variety of different audiences and regimes, ranging from the revolutionary Algerian FLN cadres (25 December 1963), the wider public in the Middle East in an interview given to the Middle East News in Cairo (20 December 1963), a formal joint declaration with Bourguiba in Tunisia (10 January 1964), communiqués and newspaper interviews in Accra (15-16 January 1964), formal communiqués with Guinea (26 January 1964), Sudan (30 January 1964) and Ethiopia under Haile Selassie (1 February 1964), and a speech at a mass rally in Mogadishu (3 February 1964). The rhetoric was pragmatically tucked and trimmed to suit the particular host and occasion, but two core themes were repeated, with varying degrees of emphasis throughout: China's imagined fraternity with African anti-colonial and developmental struggles, and China's support for Africa in overcoming these challenges, both morally and practically. Thus in Accra, Zhou's responses to a public press conference stressed China and Africa's general "shared experience of suffering from imperialist and colonial aggression" with the core message of "consolidating national independence, safeguarding state sovereignty, developing national economy, promoting Asian-African solidarity, and defending world peace," as well as emphasizing bright prospects ahead, and reiterating China's eight principles for granting economic and technical assistance. $^{5}$ In contrast, before the more familiar audience of the FLN in Algiers, Zhou drew clear parallels between the great revolutionary struggle of the Algerian Liberation Army and the experience of the Chinese Communist Party in language that could have been directly reprinted from Mao's propaganda of the civil war period and early years of regime consolidation:

5 “Premier Chou En-lai answers newsmen's questions in Accra," Peking Review, No. 4, 24 January 1964, pp. $15-16$. 
Newborn revolutionary forces, though seemingly weak at first, can ultimately defeat the outwardly strong but decadent counterrevolutionary forces ... the Algerian revolutionaries have been able to persist in struggle and win victory under extremely difficult conditions because they go deep into and around the masses and they have formed the broadest possible antiimperialist national united front by uniting the workers, peasants, revolutionary intellectuals and all forces that can be united.... We are glad to see that ... the Algerian people, under the leadership of President Ben Bella and the FLN, are united in a resolute struggle against all kinds of disruptive schemes of the colonialists, are successfully pushing ahead the revolutionary cause and are determined to take the socialist road. ${ }^{6}$

Interestingly, it was not only the Algerian anti-colonial struggle, with its obvious parallels with the people's war experience of the Chinese Communist Party, which merited this linkage: even the conservative (indeed imperial) Haile Selassie government of Ethiopia was described in glowing terms that resonated with an analogously lengthy Chinese past:

With its history of more than 3,000 years, Ethiopia, like other countries in Africa, is known for its ancient civilization. The people of Ethiopia, with a long tradition of battling imperialism, have carried on consistent struggle against aggressors since the 16th century. Led by the present Emperor, they were victorious in their heroic fight against Italian fascist aggression. Afterwards, they continued to strive to safeguard their national independence and develop the national economy. ${ }^{7}$

History was also manipulated to claim links with Sudan through the particularly villainous figure of General Charles "Chinese" Gordon, a British colonial officer of the mid to late 19th century. Gordon is an extremely unusual case of a colonial-era individual who served - with an excessive accompaniment of bloodiness - in both China and Africa. Gordon first appears in China as present at Lord Elgin's raid on the Yuanmingyuan in Beijing in October 1850, an incident that is to this day remembered as one of the more egregious imperialist outrages. Some ten years later, Gordon helped supply knowledge and leadership to aid the Qing court in its suppression of the Taiping rebellion. He met his end after a spell as governor of Sudan "in an armed revolt by the Sudanese people" (the Mahdist uprising). Thus the imperial "yellow jacket" given to Gordon by the Qing emperor in gratitude for services rendered in putting down the Taiping rebellion now in the Khalifa Museum serves as a tangible reminder of "the common colonial past of the Chinese and Sudanese peoples," 8 as Zhou said in 1965, and is a standard tour stop for visiting Chinese delegations to Sudan even today.

But the best articulation of principles during Zhou's first major tour was given in Somalia, in a formal address to a mass rally in Mogadishu on 3 February 1964. This typically looked both back and forward. His speech was based on a reiteration of the long-standing familiarity and friendliness of relations between

6 Extremely embarrassingly, given China's effusive support for the FLN in general and Ben Bella in particular, less than two years after this speech China caused widespread offence in Africa when, desperate to stage a second Bandung conference in Algiers later in 1965, it raced to recognize the new military government in Algeria that had just deposed Ben Bella. Zhou Enlai, "African people's example of daring to wage armed struggle and seize victory: Premier Chou En-lai addresses the Algerian FLN meeting," full text reproduced in Peking Review, No. 1, 3 January 1964.

7 "Premier Chou En-lai's visit to East Africa," Peking Review, No. 6, 7 February 1965, p. 29.

8 Ibid. p. 28. 
the Chinese and Somali peoples, beginning with indirect trade and the Zheng He voyages before being "interrupted by colonial aggression after the 16th century" and now restored and developed under new historical conditions to a state of "comrade-in-arms" status. Zhou reaffirmed the broad commonality of experiences between China and Africa: "Although the Chinese people and the African peoples speak different languages and are thousands of miles apart, we have similarly experienced aggression and oppression by imperialism and colonialism, and we face the common fighting tasks of opposing imperialism and building up our respective countries. We understand each other best and we share each other's feelings." Zhou then suggested a heady, optimistic future of a properly "awakened" and "new" Africa that almost perfectly replicated a long-standing domestic Chinese discourse of a "new" and "awakened" China": "in the cause of creating a new human civilization, the African peoples who have created a glorious ancient civilization will certainly leave far behind the Western civilization which was based on colonial rule over the peoples of Africa, Asia and Latin America."

China's practical means to support this was based on the Five Principles of Peaceful Co-existence, the ten principles of the Bandung Conference, and its own principles in providing economic aid on the basis of equality and mutual benefit. ${ }^{10}$ Proclaiming "the national and democratic revolutionary movements in Asia, Africa and Latin America"11 at the forefront of human history enabled the PRC implicitly to draw on its own recent historical past of struggle and consolidation to position itself rhetorically as only slightly "ahead" of Africa, able and willing to understand and assist in the spirit of fraternity and progress, and to do so in a way that was able to pay respect and reassure even non-Marxist-Leninist regimes.

\section{Amity, Sacrifice and the Big Project: TAZARA and Rhetorics of Development}

The TAZARA "friendship" railway was from the outset a special showcase development project, taken on to fill a gap for Africa that Western finance and engineering had publicly declined to take up. Although unofficial preliminary surveying was undertaken in 1965, everything about the actual official implementation - from the formal and public commitment to build it in September 1967 to the surveying and actual construction - was temporally framed by the Cultural Revolution "decade of chaos" from 1966 to 1976. In Snow's account, the Chinese engineers finally returned home in July 1976,12 less than two months before the death of Mao and three before the fall of the Gang of Four. A full

9 John Fitzgerald, Awakening China: Politics, Culture and Class in the Nationalist Revolution (Stanford: Stanford University Press, 1996).

10 "Premier Chou En-lai: revolutionary prospects in Africa excellent!"

11 Ibid.

12 Snow, The Star Raft, p. 170. 
assessment of the TAZARA project could run to several book-length manuscripts, and at least one scholar is currently making this particular effort. ${ }^{13}$

For present purposes, two things about the TAZARA project stand out. First was how relatively well insulated it was from the overwhelming instability and vicious factionalism that were such chronic features of domestic political life in China during this period. Second was how absolutely, even at the height of the Cultural Revolution, the supporting rhetoric for the "friendship" railway continued to trumpet the eight principles of friendly aid unchanged from the Zhou Enlai tours of 1963-65, and draw on a set of norms that were at the core of revolutionary China's conception of its best self: egalitarian, selfless, advancing towards modernity and doing so in its own way. Of the eight principles of friendly aid, four in particular stressed the domestic depictions of the project: China's commitment to equality and mutual benefit to help the economies of friendly emerging countries, strictly respecting sovereignty, training the personnel of the host country to master the new equipment, and perhaps most of all, directing the Chinese technicians sent to Africa to have only the same standard of living as experts in the host country.

In this way the technical mission to build the railway fulfilled a long-standing foreign policy goal: the completion of a big, visible and important infrastructural project that distinguished China and Chinese aid as separate and better when in direct competition with the West. At the same time, the TAZARA project was implemented in a way that resonated with Maoist revolutionary repertoires and practices: a long-term campaign manned by a corps of specially chosen new revolutionary heroes, enjoined to reinvigorate Maoist revolutionary models of China's cadres and technicians as selflessly sacrificing while maintaining all important "close links with the people."

The official depiction of the early stages of the project painted an idealized picture of amity, comradeship, mutual heroism, and commitment to a shared future of national independence, development of national economies, and opposition to imperialism and colonialism. The revolutionary, and indeed explicitly military, nature of the campaign to complete the surveying drew on a repertoire of revolutionary method and practice that stretched back to the Long March and Yan'an periods in the Chinese Communist Party's own legitimating founding history:

The Chinese personnel and the Tanzanian and Zambian workers battled side by side, hacking their way through the jungle and bushes ... day after day, they worked under scorching equatorial sun and in tropical downpours ... indefatigably, they overcame all kinds of difficulties in their way and, step by step, completed the survey and designing of the railway. ${ }^{14}$

13 See Jamie Monson, Africa's Freedom Railway: How a Chinese Development Project Changed Lives and Livelihoods in Tanzania (Bloomington: Indiana University Press, 2009), and "One helps one, two become red: Chinese and Africans at work on the TAZARA railway, 1965-1986," work in progress.

14 "Friendship in hard struggle: account of China's surveying and designing team which helps build the Tanzania-Zambia railway," Peking Review, No. 43, 24 October 1969, pp. 32-33. 
With only slight changes in vocabulary, exactly the same was said in the official propaganda about the heroic Long March of 1934-35, which passed through extraordinarily difficult terrain, and relied on the power of human will and comradeship to overcome extreme obstacles before eventual and inevitable triumph.

Heroism in battling against nature as part of a grand developmental project was reinforced by a set of other tropes of the true and sincere revolutionary cadre common to other Chinese aid projects at the time from agricultural aid to medical clinics. The plain and simple living of Chinese "friends" and technicians, close links to the people, fraternal assistance, the gratitude of locals, and the positive comparisons made between Chinese and Western aid were constantly reiterated. In one account: "Those foreigners who were here before ... never went into the fields because they were afraid their clothes might get dirty. But the Chinese friends go through thick and thin with us. Our sweat and theirs fall on the same plot of land." 15

All this rhetoric at the beginning of the project gave little indication of what was ahead: the reality of the irritations, design flaws, problems with local brain drain and training, and the "inefficient" bureaucracy that TAZARA would become. The "friendship" railway was large in scale, visible, unusually challenging in terms of topography and engineering, and with a lasting and tangible (if not hugely well functioning) product emblematic of shiny modernization: a gauntlet thrown down to the West that the West had publicly declined to pick up. Predictably for such a large project, in practical terms there were any number of problems with maintenance and ongoing cost overruns. But the way in which China imagined and depicted its own success is interesting in its own right. The success of the railway was ascribed to elements that were in microcosm projections of China's best revolutionary self: the commitment and selflessness of individuals both "red and expert," devoted to service and sacrifice, working with close links to the people, reliance on human will to achieve extraordinary and quick results, and above all an investment as much emotional as practical.

In China, astonishingly little of this Cultural Revolution era rhetoric of the "friendship" railway has dated; it still features prominently in contemporary discourse on China-Africa as "a monument of China-Africa friendship" and development. ${ }^{16}$ The first ten minutes of episode 5 of the contemporary CCTV series Sharing a Common Fate, "A new chapter in co-operation (China's investment in Africa)" is devoted to the TAZARA project. The segment opens with a shot of the railway and an announcer, reading in a deep but unmistakably American-English intonation: "known to every Chinese ... it all started back

15 See in particular "Seeds of friendship - Chinese agricultural technicians help build rice and tobacco experimental station in Somalia," Peking Review, No. 48, 28 November 1969.

16 "A chronology of China-Africa relations - Beijing review," and an extended first segment in the CCTV documentary, "China's investment in Africa," part of the China and Africa, Sharing a Common Fate documentary series. This was broadcast on CCTV 9 in December 2007, and has since been posted on YouTube by geneofisis. 
in the 1960s, shortly after Tanzania and Zambia had freed themselves from British colonial rule."

The film then jumps to black-and-white archive footage of the signing of the agreement for the project in Beijing on 5 September 1967 (ironically at the height of the public instability during the Cultural Revolution), with a clearly uncomfortable and jumpy Zhou Enlai preparing to sign the documents. The announcer then continues: "The news created shock waves across the Western world. Premier Zhou said that the railway was being built not only for Tanzania or Zambia, but for the whole African continent." Friendship, struggle, danger, heroism and an undercurrent of successful competition with the West are all conveyed in the next few moments of voiceover and images. Archive footage shows a mixed group of Chinese and African surveyors at work, before cutting to running giraffes and sleeping leopards, and then to a landrover moving through dense foliage: "The Chinese survey teams struggled through the unpopulated and animal-filled African jungles to open up roads and conduct survey work ... they faced constant hardship and danger. The railway would cut across vast desolate areas." To shots of dynamite exploding and mixed construction teams at work, the announcer intones: "In the course of two years the Chinese surveyors walked for more than $5,000 \mathrm{~km}$ to draw up the blueprint for the future railway. On the front line, the Chinese construction team braved the extreme heat, shortages of food and medicine, and the difficulties of transport and communication. Above all it was the shortage of water that was their number one problem." After a short interview with a former surveyor discussing the shortage of water, the announcer continues: "In the West it was predicted that it would take 25 years to complete the Tanzania-Zambia railway, but the Chinese finished the job in just six years."

Images of sober reflection and commemoration are also present in the programme. The Chinese technicians who lost their lives during their sojourn in Africa are commemorated as martyrs (lieshi 烈士), a term that resonates with a much older revolutionary vocabulary. The documentary goes on to interview the then Foreign Minister Li Zhaoxing 李肇星. Li, elegant and soft spoken, is filmed in a neutral office in an understated grey Western business suit, with half the red flag of the PRC just visible to the side of the frame. He speaks in Chinese with his words subtitled: "Forty-nine of our technicians sacrificed their lives in the construction work. Not long ago, Premier Wen Jiabao paid tribute at the graves of these martyrs. Building such a railroad would have been really difficult even in our own country." With a mournful piano and heavy strings on the soundtrack, the camera then jumps to 2006, with footage of Wen Jiabao laying a wreath at a grave and Tanzanians in the background, proclaiming "the people of the Motherland and Tanzania and Zambia are grateful for their selfless contribution, and their exploits will remain engraved on our hearts forever." This ceremony was also widely reported in Chinese press, as Wen (accompanied by Xinhua photographers and television cameras) "spoke highly of those Chinese who came to Tanzania and Zambia decades ago to help with 
the construction of the 1,860-kilometre railway ... the Chinese, Tanzanian and Zambian peoples would not forget these Chinese martyrs." Public and formal respect was reinforced by the accompanying Tanzanian Prime Minister's formal statement: "[He] wished the Chinese martyrs to rest in peace in a home away from home."17

The raison d'être of the TAZARA project was developmental as well as multinational and co-operative, and the documentary does not neglect this. To shots of Africans riding on the train and Africans and Chinese singing and clapping in a line together, the voiceover asserts:

The opening of the Tanzania-Zambia railway gave a great boost to the economic development ... the railway injected new dynamism into economic development all along its route. The Kilimanjaro, which runs along the Tanzania-Zambia border, was actually produced in China. The passengers are not only from Tanzania and Zambia, but also from such neighbouring countries as Congo, Kenya, Uganda and Malawi. Over the years, co-operation between the three countries, China, Tanzania and Zambia, in the field of railway construction and operation has encountered many new opportunities. In the future as in the past with the help of the Chinese people, the industrious and resourceful people of Tanzania and Zambia will work out new approaches as new circumstances demand so that this iron and steel lifeline will continue to serve the revitalization of Africa.

\section{Into the Present: Jiang Zemin's 1996 Tour}

In the roughly 30 years between the Zhou Enlai tours of the early 1960s and Jiang Zemin's state visit to Africa in 1996, there was only one high-profile Chinese tour of Africa: Zhao Ziyang's visit to ten African countries in December 1982 and January 1983 in order to "improve understanding, friendship, solidarity and co-operation and to learn from the African people." 18 This visit trod the wellworn path of old friends Egypt, Algeria, Morocco, Guinea, Tanzania and Zambia and added Gabon, Congo, Zaire, Kenya and now independent Zimbabwe.

Zhao's activities in Africa can best be characterized as "the retrenchment tour" as well as a moment of interesting transition, as China's own economic reforms were just gathering steam. For the most part, long-standing rhetorical framings remained unchanged. Within these rubrics, however, not only were there no new initiatives and little new content, but what content existed was remarkably slimmed down. The implicit and explicit message was one of austerity and self reliance for all within a wider global process of development as well as increased emphasis on practical results. Thus the shorthand of "all-weather" friendship, equality, sovereignty, opposition to imperialism, mutual support (China's support for Africa's liberation struggles; Africa's contributions to supporting China against Taiwan), and the four principles for China's economic and technological co-operation were rearticulated, but in ways that simultaneously expressed the ways in which new Deng-era values broke with the recent Maoist past. The

17 Forum on China-Africa Co-operation "Chinese, Tanzanian PMs visit cemetery of Chinese martyrs," 26 June 2006, http://www.focac.org/eng/zt/wjbff/t259977.htm, accessed 16 June 2008.

18 "Premier Zhao gives new conference in Dar es Salaam,” Beijing Review, No. 5, 31 January 1983. 
Maoist virtue of self reliance was re-asserted, but in a changed frame of acceptance of the international status quo and flexible pragmatism. "Some developed countries try to shift their economic crises on to others ... [but] these difficulties are after all temporary phenomena in the process of development." 19 However, even as Zhao made clear that there would be limits to aid as "China is also readjusting its economy and we have our own difficulties ... we must not strain to do what is beyond our country's capabilities," the message was couched in language that continued to assert shared experiences and the presumptive sympathy engendered: "It is precisely because we have difficulties that we urgently need mutual help [with Africa]."20

Thirteen years later, in 1996, when Jiang Zemin toured the six African countries of Kenya, Ethiopia, Egypt, Mali, Namibia and Zimbabwe, the framing rhetoric was identical but both content and tone had shifted significantly. Confident of economic reform, secure in his own leadership position and able to build upon the visits to Africa of three vice-premiers the year before in 1995, Jiang Zemin was able to spend more time in each African country, secure a large number of bilateral trade agreements, and even make an important speech, "Towards a new historical milestone in Sino-African friendship," to the OAU on Sino-African friendship and co-operation. ${ }^{21}$ This speech is in many ways the precursor to the FOCAC meetings of 2000, 2003 and 2006, and contains most of the themes that would feature in official representations of China-Africa relations for the new millennium.

Jiang Zemin began with a reassertion of common, shared historical experiences virtually unchanged from the 1960s: China and Africa, which "are renowned cradles of the earliest human civilizations ... [who] began to reach out to each other some 2,000 years ago," an invocation of Zheng He, the essential nature of the friendly exchanges between Chinese and African people "never have they had any conflicts between them," and mutual sympathy and support amid "both [having] suffered enormously under colonialists and foreign aggression." Jiang also went out of his way to position the current chapter of Sino-African affairs in a trajectory of the Mao generation's "joining hands in building the solid foundation of Sino-African friendship and co-operation with the forefathers of the African liberation movement," while attributing the causes of Africa's underdevelopment to prior colonial exploitation and plunder, and the ongoing "unjust and inequitable economic order left over from the past." The rhetoric of friendship, equality, respect for sovereignty, the Five Principles of Peaceful Co-existence and a special relationship grounded in history between China and Africa was unchanged, but now accommodated a very different mission statement with very different implications: "The world needs peace. Nations desire

19 "Premier Zhao gives new conference in Dar es Salaam," Beijing Review, No. 4, 24 January 1983, p. 19.

20 "Premier Zhao on his African tour," p. 24.

21 The following analysis is taken from "Towards a new historical milestone in Sino-African friendship," translated in Beijing Review, Vol. 39, No. 22, 27 May-2 June 1996, pp. 7-9. 
stability. Economies must grow and societies want progress." And, in a remarkable echo of the rhetoric of the earlier generation, China "will provide a more favourable condition and open up a broader prospect for Sino-African friendship and co-operation." Only now China will do so from an utterly different position, characterized by a set of political and economic choices in many ways the polar opposite of those that characterized the Mao era.

\section{Models for Development at FOCAC: Old Framings and Expanded Content}

Both a reflection and promoter of China's post-millennial growing presence in Africa, the Forum on China-Africa Co-operation has been held every third year since 2000, in Beijing (2000) Addis Ababa (2003) and Beijing (2006). Big, important events, these meetings have received a great deal of coverage in news, policy analysis and academia. ${ }^{22}$ The official speeches that legitimate and publicize FOCAC continue to contain calls for intensification of investment, aid and bilateral arrangements within the rhetorical framings first propagated in the Mao era: the resort to analogous histories of colonialism and national liberation, the universal desire for development, the invocation of principles of absolute sovereignty and equality, mutual aid, and the kind of unconditional, no-ties assistance that is implicitly presented as separate from and better than the West's. These older, largely unchanged rubrics provide the frame for very different, rapidly "thickening" content. ${ }^{23}$ The specific items incorporated in FOCAC official statements include support for big infrastructural projects in particular African countries, a rapid increase in bilateral trade, promotion of Chinese private enterprise in Africa as partners in development and investment, further opening of markets, cancellation of debts, pledges to increase the amount of monetary assistance and human development in a promised doubling of China's 2006 assistance to Africa by 2009, the establishment of a designated Africa development fund, setting up new development zones in Africa along the lines of China's Special Economic Zones, and vast increases in China's commitment to train African professionals. ${ }^{24}$

The older, thin rhetoric sits increasingly uneasily with the reality of such a large and varied range of new proposed initiatives. Official and semi-official speeches continue to be topped and tailed with the invocation of analogous pasts of underdevelopment, suffering at the hands of imperialism, and China's presumptive superiority in being an "all-weather" friend, but this minimalist discourse is

22 See particularly Christopher Alden, China in Africa (London: Zed, 2007), pp. 27-32, and Kenneth King, "Aid within the wider China-Africa partnership: a view from the Beijing summit," available at http:/l www.cctr.ust.hk/china-africa/papers/King,Kenneth.pdf, accessed 8 February 2008.

23 Special thanks to Dan Large for pointing this out.

24 For this last set of pledges, see Hu Jintao, "Address to the Forum on China-Africa Co-operation at the opening ceremony of the Beijing summit," Beijing, 4 November 2006, available in full text at http:/www. focac.org/eng/wjjh/t404125.htm, accessed 1 July 2008. 
now looking more than a little threadbare in the light of China's actual involvement in Africa and its ever-increasing global presence. China can hardly claim analogous poverty and suffering from its current vantage point of high growth rates for the past 20 years and its steady movement into the ranks of middle-income countries as an aspiring economic superpower. Furthermore, its new prominence as power broker in troubled environments such as Sudan clearly stretches its continued iteration of the principles of non-interference and respect for absolute sovereignty to a breaking point of credibility.

Perhaps in implicit recognition of the limits of the old rhetoric, FOCAC official speeches and documents have begun to incorporate quite different notions of complementarity, international division of labour between China and Africa, and the positive effects of globalization for both. Older tropes of analogous commonality, suffering and underdevelopment are still very far from being replaced in entirety, but both Jiang Zemin (2000) and Wen Jiabao (2003) have opened FOCAC summits with reference to "China [as] the largest developing country in the world and Africa [as] the continent with the largest number of developing countries." This statement implies that China offers an older model of development (and that all Africa has to do is sort through the parts of the model most suitable to itself), while also hinting at notions of complementarity and comparative advantage. Perhaps because ambiguity here is useful, most official pronouncements have refrained from spelling out the political and economic implications of China being the largest developing country and Africa the continent with the most developing countries. ${ }^{25}$

A clearer hint of a new way of thinking about China and Africa is present in Zhu Rongji's closing speech at the first FOCAC meeting in Beijing. Zhu clearly envisages China-Africa economic and trade co-operation as part of an optimistically forward-looking take on globalization, rooted as much in complementarity, difference and interdependence as in similarity and shared historic struggle: "Africa, on the one hand, boasts talented and hardworking people, abundant natural resources, and great market and development potentials [sic]. China, on the other hand, has got considerable economic strength, a promising market and a wealth of commodities, managerial expertise and production technologies suitable to African countries." ${ }^{26}$ But it is notable that even a globalization-and-reform-minded minister like Zhu Rongji was in 2002 unable to jettison older legitimating rhetoric in entirety. His speech ends with the ritual invocation of "the joint struggle waged by Chinese and African peoples shoulder

25 Jiang Zemin, "China and Africa usher in a new century together," speech at the opening ceremony at the Forum on China-Africa Co-operation, Beijing, September 2000, http://focac.or/eng/wjjh/t404120. $\mathrm{htm}$, accessed 16 June 2008; this wording was repeated verbatim by Wen Jiabao at the opening ceremony for FOCAC in Addis Ababa, 15 December 2003, http:/www.focac.org/eng/wjjh/t404119.htm, accessed 16 June 2008.

26 Zhu Rongji, "Strengthen solidarity, enhance co-operation and pursue common development," speech given at the closing ceremony of FOCAC, Beijing, 12 October 2002, http://www.focac.org/eng/wjjh/ t404118.htm, accessed 16 June 2008. 
by shoulder," the unconditionality of China's assistance, and "stand[ing] together through thick and thin, clos[ing] ranks, enhanc[ing] co-operation, and seek[ing] common development."27

\section{Rhetorical and Developmental Claims: Historicizing the China-Africa Relationship in an Age of Expanded Content and New Audiences}

This article has charted China's official discourse on its relationship with Africa, and noted a range of unexpected continuities from the 1960 s to the present. I do not argue that "plus ça change, plus c'est la même chose"; indeed the outstanding curiosity is why the rhetoric has changed so little while so much of the content of China-Africa relations is undergoing profound changes. China's rhetoric on China-Africa, and the surprising longevity of its framing notions, in all likelihood has as much to do with the leadership's desire to reaffirm credibility and standing with the audiences deemed most important in both China and Africa than it does with analytical accuracy in portraying the "realities" of what is in fact happening in a range of African environments.

State and foreign policy making elites the world over may well hold on to older legitimating rhetorics despite their tensions with empirical reality, precisely because a long-standing set of rhetorical tropes is likely to encapsulate what core audiences want and need to hear, and because jarring the sensibilities and deeply held values of those constituencies may be very risky, particularly when they are important on the domestic political scene. Which particular audience the propagators of official rhetoric most care about appealing to, winning over or consolidating support from does of course vary over time. The domestic and foreign leftist audiences China most cared about when in competition with the Soviet Union in the 1960s and 1970s were by the early 1980s deemed irrelevant, and those parts of the rhetoric that stressed China's support for movements of national liberation (in Africa and elsewhere) simply dropped from the foreign policy discourse.

More trickily, core audiences to whom the state wishes to appeal may themselves change in orientation, and do so quite quickly. Until quite recently, China could count on sympathetic African political elites for rock solid support for its principles of non-intervention and respect for absolute state sovereignty. In Africa these notions still resonate positively for many. But this long-standing consensus is now undergoing severe questioning within Africa itself, most notably in the relatively new principle of "non-indifference" enshrined in the African Union's Constitutive Act of 2002. ${ }^{28}$ The legitimacy of "non-indifference" in both principle and practice may well be contested within Africa. But it is undeniably now part of official African Union policy, has been vigorously 
promoted by Konaré, chair of the African Union Commission, and was directly invoked in sending in peacekeeping troops for the crises of Darfur and Somalia. ${ }^{29}$ China's ongoing attachment to what appears to be superannuated and logically untenable rhetorics of absolute state sovereignty and noninterference, as well as its implicit superiority as a model to the West, continue to be attractive to core groups within China, even as audiences change, norms shift and new rhetorical vocabularies of legitimation are in the process of emerging outside China. Even more problematically, the realities of China's multilayered involvement in a range of African environments - most obviously in Sudan but also present in other countries - means that "interference" is both inevitable and likely to come under increasing scrutiny. How the official and semi-official rhetoric will adapt in the light of these changes - enough to be credible amongst African elites while continuing to resonate with what Chinese domestic audiences want and expect to hear about themselves and their government - remains to be seen.

For the present at least, how the history of China's relations with Africa is understood, interpreted and reiterated provides a legitimizing and framing outline for the rhetoric, which in turn continues to accommodate a great deal of new content. The Zheng He voyages of the Ming are recreated in documentaries and foreground most general official discussions of China-Africa relations, but what is being implicitly asserted through this version of history is the longstanding non-aggressive, peaceable and trading intentions of (the People's Republic of) China towards Africa in implicit contrast to the colonial and exploitative West both historically and in the present. China explicitly claims special friendship with Africa on the basis of a common history of colonialism and developmental needs. The PRC's own long-standing, no-ties development assistance as characterized by Maoist heroic projects and close links to the African people continues to be invoked as a positive norm, and Chinese technicians who lost their lives in these projects are still celebrated as heroic "martyrs," in a political and social environment in which virtually every other aspect of Maoism has been savagely repudiated.

These particular continuities suggest a set of larger continuities in the Chinese state's claims from the Maoist period to the present that are of continued legitimating value: not only is China an old and "splendid civilization," but it is at the vanguard of the future, unusually grounded in morality in being untainted by colonialism and neo-colonialism. As such China is of the developing world, but has found its own path to development that it is now able to share with Africa through a wide range of measures including loans, projects, training, joint ventures and export processing zones - measures that are simultaneously separate from and presumptively better than the West's. The combination of

29 "Chairperson Konaré urges African Foreign Affairs Ministers to respect the principles of democracy," Addis Ababa, 28 January 2008, http://www.africa-union.org/root/au/Conferences/2008/january/summit/ docs/CP/Summit\%20-\%EXECUT, accessed 29 December 2008. 
greater scrutiny from different social groups and often vigorous civil society in Africa, international pressure over particular bilateral relationships, and the harder realities and complexities of a relationship that is varied, complex and characterized as much by realpolitik as friendship to the African people may well prompt eventual adjustments to the rhetoric; it will be interesting to see in which ways and by how much in the years to come. 